\title{
MANUAL DE CAMPAMENTOS DEL FRENTE DE JUVENTUDES (EDICIONES DE 1943 Y 1948): VARIACIONES EN TORNO A LA CULTURA POLÍTICA Y LA DISCIPLINA DE LOS CUERPOS EN LA ESPAÑA FRANQUISTA
}

\author{
Camp Manual of the Spanish Youth Front (Frente \\ de Juventudes), editions of 1943 and 1948: variations around \\ the political culture and the discipline of the bodies \\ in Franco's Spain
}

\section{Emilio Castillejo Cambra ${ }^{\alpha}$}

Fecha de recepción: 05/06/2019 • Fecha de aceptación: 20/01/2020

Resumen. Este artículo analiza y compara las ediciones de 1943 y 1948 del Manual de campamentos, que instruye a los mandos de campamentos del Frente de Juventudes, el equivalente franquista de los Balilla mussolinianos y de las Hitler-Jugend nazis. En estos manuales, el campamento aparece como un microcosmos que refleja la estructura orgánica y práctica gubernamental del Estado franquista, incluidos sus aspectos biopolíticos: sanidad, almacenamiento de alimentos, consumo de calorías... La cultura política que trasmiten y sus variantes guardan una afinidad con la normalización de los cuerpos de los acampados: la subcultura falangista impone en los cuerpos la fuerza, la marcialidad, la rectitud; la subcultura católica, la mansedumbre, formas sinuosas. Las dos ediciones del manual reflejan, además, la evolución del régimen franquista: en la de 1943, el panóptico del Jefe de campamento refleja la fascistización del Estado; en la de 1948, la legitimación de la encíclica Divini Illius Magistri o la imposición de una pedagogía cristiana (principio de autodirección) hablan del establecimiento de un Estado católico, de la cultura del súbdito participante, afín a una nueva normalización de los cuerpos (mayor distensión, líneas oblicuas), sin que desaparezcan las formas de control

\footnotetext{
a Departamento de Geografía e Historia. Centro Asociado UNED-Pamplona. Carretera de Sadar, s/n. 31006. Pamplona. España. ecastillejo@Pamplona.uned.es.
}

Cómo citar este artículo: Castillejo Cambra, Emilio. «Manual de Campamentos del Frente de Juventudes (ediciones de 1943 y 1948): variaciones en torno a la cultura política y la disciplina de los cuerpos en la España franquista». Historia y Memoria de la Educación 13 (2021): 503-540 
tradicionales o los movimientos automáticos (desfiles, formaciones), propias de la cultura del súbdito que da unidad al franquismo.

Palabras clave: manual de campamentos; Frente de Juventudes; franquismo; cultura política; disciplina de los cuerpos.

Abstract. This article analyzes and compares the 1943 and 1948 editions of the Camp Manual, which provides instructions for the camp commanders of the Youth Front, the Francoist equivalent of Mussolini's Balilla and the Nazi Hitler-Jugend. In these manuals, the camp appears as a microcosm that reflects the organic structure and government practice of the Francoist State, including its biopolitical aspects: health, food storage, calorie consumption... The political culture that they transmit and its variants maintain an affinity with the normalization of the bodies of the campers: while the Phalangist subculture imposes strength, martiality and rectitude upon the bodies, the Catholic subculture imposes meekness and sinuous forms. The two editions of the manual also reflect the evolution of Franco's regime. In the 1943 edition, the leaflet of the camp leader reflects the Fascistization of the State. The 1948 edition, on the other hand, stresses the legitimization of the encyclical Divini Illius Magistri or the imposition of a Christian pedagogy (principle of self-direction), and it speaks of the establishment of a Catholic State. This includes the concept of the culture of the participative subject, linked in turn to a new normalization of the bodies (greater distention, oblique lines), without this implying the disappearance of the traditional forms of control or the automatic movements (parades, formations), characteristic of the culture of the subject that gives unity to Francoism.

Keywords: camp manual; Youth Front; francoism; political culture; discipline of the bodies.

Este artículo analiza y compara la segunda (1943) y cuarta edición (1948) del Manual de campamentos ${ }^{1}$ publicado por el Frente de Juventudes (FJ) de Falange Española Tradicionalista y de las Juntas de Ofensiva Nacional Sindicalista (FET-JONS), que el Decreto de Unificación de abril de 1937 establece como partido único del régimen de Franco. ${ }^{2}$ El FJ, adscrito a FET-JONS, pretende encuadrar y formar a la juventud española

\footnotetext{
1 Delegación Nacional del Frente de Juventudes, Manual de campamentos (Madrid: Ediciones Frente de Juventudes, 1943), 2. ${ }^{\text {a }}$ ed. 200 págs. Delegación Nacional del Frente de Juventudes, Manual de campamentos (Madrid: Ediciones Frente de Juventudes, 1948), 4. ${ }^{\text {a }}$ ed. reformada y aumentada. 481 págs.

${ }^{2}$ Falange Española (FE) de José Antonio Primo de Rivera, fundada en 1933, se une en 1934 con otro partido fascista, Juntas de Ofensiva Nacional Sindicalista (JONS). Por el Decreto de Unificación de abril de 1937 Franco fusiona FE-JONS con Comunión Tradicionalista y monárquicos alfonsinos, dando lugar a Falange Española Tradicionalista y de las JONS (FET-JONS), partido único del
} 
con actividades como la organización de campamentos. ${ }^{3} \mathrm{Si}$ los manuales del acampado pretenden instruir a este, los manuales de campamentos dan instrucciones teóricas y prácticas a sus mandos.

Siendo el manual de campamentos un acto de comunicación, analizo aquí los elementos que intervienen en el mismo: mensaje, contexto, canal, código, receptor y referente. ${ }^{4}$ El emisor (Delegación Nacional del Frente de Juventudes) y el canal (Ediciones del Frente de Juventudes) de las ediciones de 1943 y 1948 coinciden: los cambios en el mensaje derivan sobre todo de los contextos en que surgen: durante y después de la Segunda Guerra Mundial.

Esos manuales inculcan una cultura política, integrada por elementos doctrinales, intelectuales y afectivos, inseparable de distintas formas de control corporal. Conviene empezar aclarando estos términos. Para Gabriel A. Almond y Sidney Verba, cultura política es el conjunto de valores y actitudes relativos al sistema político, que puede integrar subculturas o variantes de la misma. ${ }^{5}$ En este caso, la cultura que legitiman es la franquista, que encaja bien con lo que estos autores llaman cultura política del súbdito, basada en la obediencia pasiva, aunque, como veremos, la edición de 1948, al incluir el concepto de autodirección, encajaría bien con la cultura del súbdito participante. El falangismo, lo mismo que el catolicismo, se comporta en estos manuales como una subcultura, un estrato particular que pierde peso a lo largo del tiempo. ${ }^{6}$ Además

régimen. Sobre la actitud posibilista o rigorista de esas fuerzas ante la integración: Joan Maria Thomàs, Lo que fue la Falange (Barcelona: Plaza y Janés, 1999), 131-221.

3 Juan Sáez Marín, El Frente de Juventudes. Política de juventud en la España de la posguerra, $1937-$ 1960 (Madrid: Siglo XXI, 1988), 411: define un campamento como una instalación dotada de tiendas de campaña y servicios que permiten actividades en la naturaleza. César Fernández Quevedo Rubio, "Las actividades de "Aire libre» en la Organización Juvenil y el Frente de Juventudes» (Tesis doctoral dirigida por Emilia Fernández García y Elena Ramírez Rubio, Universidad Complutense. Facultad de Educación. Departamento de Expresión Musical Corporal, Madrid, 2018), 136-143, clasifica los campamentos según su localización (mar, montaña), finalidad (formación de mandos, iniciación o captación), ámbito geográfico (provinciales, nacionales), y participantes (Falanges Juveniles de Franco, Escolares, Aprendices y Rurales).

4 Método propuesto por Emilio Castillejo, «Análisis del contenido ideológico de los manuales de Historia», Bordón Vol. 61-2 (2009): 45-57.

5 Gabriel A. Almond y Sidney Verba, «La cultura política», en Diez textos básicos de Ciencia Politica, ed. Albert Batlle (Barcelona: Ariel, 1992), 171-201.

${ }^{6}$ En los manuales de Religión católica, en cambio, este credo es la cultura política legitimada: el neointegrismo o el aggiornamento se comportan en ellos como subculturas o estratos particulares: 
de elementos intelectuales y cognitivos, una cultura política integra también afectos y emociones, que cada vez pesan más en la investigación histórica-educativa. ${ }^{7}$ José Ángel Ascunce, en un trabajo reciente sobre sociología cultural del franquismo, junto con los mecanismos represivos e ideológicos, identifica mecanismos emocionales de evasión (literatura de masas, deporte) que legitiman el régimen. ${ }^{8}$ Comprobaremos su presencia en los manuales que comentamos.

La tecnología política del cuerpo, el control de los cuerpos de que habló Michel Foucault, es inseparable también de una cultura política. El «modo de ser» que pretenden inculcar las actividades del campamento, además de conceptos y afectos, incluye una normalización de los cuerpos de los acampados, que guarda relación con los poderes disciplinarios que ese autor identificó en la prisión, el ejército, la escuela, la fábrica, poderes que normalizan los cuerpos de los individuos a través de prácticas de medición de comportamientos y disciplinas científicas como la medicina y la psiquiatría: el individuo se convierte así en un «objeto analizable» y el saber en un «saber poder». ${ }^{9}$ En Historia de la sexualidad Foucault empieza a hablar de biopolitica para referirse a la normalización de las colectividades. ${ }^{10}$ La biopolítica es la forma que se impone desde el siglo XVIII de «racionalizar los problemas planteados a la práctica gubernamental por los fenómenos propios de un conjunto de seres vivos constituidos como población: salud, higiene, longevidad, razas...».11 En este sentido, el campamento, una «ciudad de lona», prefigura al Estado franquista en un doble sentido: primero, porque cuenta con infraestructuras sanitarias, logísticas, administrativas...; segundo, porque

Emilio Castillejo, La enseñanza de la Religión católica desde la Transición (Madrid: La Catarata, 2012), 34-35.

${ }^{7}$ Miguel Somoza, Kira Mahamud y Heloisa Helena Pimienta, «Emociones y sentimientos en los procesos de socialización política: una mirada desde la Historia de la Educación», Historia y memoria de la Educación 2 (2015): 7-44.

8 José Ángel Ascunce, Sociología cultural del franquismo, 1936-1975 (Madrid: Biblioteca Nueva, 2015), 239-429.

${ }_{9}$ Michel Foucault, Vigilar y castigar. Nacimiento de la prisión (Madrid: Siglo XXI, 1992), 30-35, 166198, 226-229. También: Michel Foucault, Microfísica del poder (Madrid: Ediciones La Piqueta, 1992), 139-157; Michel Foucault, Un diálogo sobre el poder (Madrid: Alianza, 1988), 128-145.

10 Michel Foucault, Historia de la sexualidad. I. La voluntad de saber (Madrid: Siglo XXI, 1992), 4347, 80-88, 109-139, 164-184.

${ }_{11}$ Michel Foucault, Nacimiento de la biopolítica (Madrid: Akal, 2016), 311. 
el campamento funciona como un microcosmos orgánico, un cuerpo: el objetivo de la práctica gubernamental es mantener la unidad y vitalidad de ese cuerpo. En su momento, Ernst Kantorowicz habló de «los dos cuerpos del rey»;12 aquí, aunque en un sentido muy distinto, podemos hablar también de un doble cuerpo, el del campamento como todo orgánico y el de los acampados.

En el control del cuerpo no solo intervienen poderes extraños al mismo, sino los propios cuerpos a través del automatismo, la mímesis y el adiestramiento. Norbert Elias estudia cómo, a través de la autocoacción, progresivamente los modos cortesanos (el courtois) se imponen en la aristocracia del Antiguo Régimen, la burguesía ascendente y las clases populares. ${ }^{13}$ Marcel Mauss incide en el papel del adiestramiento y la mímesis en la naturalización del habitus o usos del cuerpo. ${ }^{14}$ Pierre Bourdieu ve en el habitus una estrategia de distinción que se reproduce hasta adquirir la apariencia de algo innato: ${ }^{15}$ al estudiar la cabila argelina, comprueba cómo el habitus (gestos, formas de actuar) que distingue a los cuerpos masculinos dominantes y femeninos dominados, se naturaliza, se reproduce y trasmite sin necesidad de la conciencia o del discurso. ${ }^{16}$ Comprobaremos que el adiestramiento y el automatismo no son ajenos tampoco a las prácticas campamentales.

Empieza a ser tradición el uso de estos conceptos por la historia educativa. Salvador Cayuela estudia la biopolítica de la España de Franco desde un punto de vista socioeconómico (control de la fuerza del trabajo), médico-social (psicología racista de Vallejo Nájera) e ideológico (papel del FJ), que produce el homo patiens, resignado y sumiso, que entró en crisis con el neocapitalismo desarrollista y la incipiente sociedad de

12 Ernst Kantorowicz, Los dos cuerpos del rey. Un estudio de teología política medieval (Madrid: Akal, 2012).

13 Norbert Elias, El proceso de la civilización. Investigaciones sociogenéticas y psicogenéticas (Madrid: FCE, 1993), 228.

${ }^{14}$ Marcel Mauss, Sociología y antropología (Madrid: Tecnos, 1979), 337-356. También Jaime de la Calle Valverde, «El gesto analógico. Una revisión de las técnicas del cuerpo de Marcel Mauss», Revista Latinoamericana de Estudios sobre Cuerpos, Emociones y Sociedad 7 (dic. 2011-marzo 2012): 75-87.

15 Pierre Bourdieu, Cuestiones de sociología (Madrid: Istmo, 1999), 31, 81, 92, 112-119, 132-135, 196; Pierre Bourdieu, Meditaciones pascalianas (Barcelona: Anagrama, 1999), 169-214.

16 Pierre Bourdieu, La dominación masculina (Barcelona, Anagrama, 1999), 5, 7, 13-14, 24, 28-38, 69. 
consumo. ${ }^{17}$ Marta Mauri aborda el control de los cuerpos a través de la Educación Física: uniformes que borran el individualismo, insignias que marcan jerarquías, conjunto armónico de la formación. ${ }^{18}$ Esta misma autora comprueba que las actividades deportivas organizadas por el FJ en los centros educativos o en los campamentos, suponían un programa de intervención en los cuerpos de niños y jóvenes para crear un tipo concreto de ciudadano y formar soldados y trabajadores que perpetuaran el régimen franquista. ${ }^{19}$ Parece pertinente, por tanto, comprobar cómo interactúan en los manuales de campamentos cultura política y control corporal en la legitimación del franquismo.

\section{MANUAL DE CAMPAMENTOS: CONTEXTOS, CANAL Y EMISOR}

Los contextos históricos determinan en buena medida los cambios en el mensaje de ambas ediciones. La 2. ${ }^{a}$ edición del Manual de campamentos (1943), como veremos, describe algo parecido a un Estado totalitario. De hecho, la dictadura de Franco está adquiriendo esas características, se acerca a las potencias del Eje (entrevista de Hitler y Franco en Hendaya en octubre de 1940, con Mussolini en Bordighera en febrero de 1941, envío de la División Azul al frente ruso, 1941-1943), si bien, desde la destitución de Ramón Serrano Suñer (1942) comienza un tímido acercamiento a los aliados, acentuado tras la caída de Mussolini (1943) y el desembarco de Normandía (junio de 1944). ${ }^{20}$ FET-JONS, partidaria del Estado totalitario y del intervencionismo, no puede ocultar - tampoco el manual que comentamos- la distancia entre la retórica revolucionaria del partido y su realidad ideológica (contaminada, incluso antes del Decreto de Unificación, por el catolicismo y el

\footnotetext{
17 Salvador Cayuela, Por la grandeza de la Patria. La biopolítica en la España de Franco, 1939-1975 (Madrid: FCE, 2014); Salvador Cayuela, «El nacimiento de la biopolítica franquista. La invención del "homo patiens"», Isegoría, 40 (enero-junio 2009): 273-288; Salvador Cayuela, «La biopolítica del franquismo desarrollista: hacia una nueva forma de gobernar, 1959-1975», Revista de Filosofía Vol. 38-1 (2013): 159-179.

18 Marta Mauri, «Mens sana in corpore sano. La Educación Física del Frente de Juventudes y el disciplinamiento de los cuerpos», Actas del XVIII Coloquio de Historia de la Educación: Arte, literatura y educación, Vol. 1 (2015), 381-391.

19 Marta Mauri, «Disciplinar el cuerpo para militarizar a la juventud. La actividad deportiva del Frente de Juventudes en el franquismo (1940-1960)», Historia Crítica 61 (julio-septiembre 2016): 100-101.

20 Javier Tusell, Historia de España en el siglo XX. III. La Dictadura de Franco (Madrid: Taurus, 1998), 106-164.
} 
tradicionalismo), social (dominio de clases elevadas) y política: entendimiento con fuerzas monárquicas en la conspiración de 1936; sometimiento de sus milicias al Ejército durante la Guerra Civil; subordinación del partido al Caudillo que aprueba sus estatutos en agosto de 1937, depura disidentes (Manuel Hedilla, Salvador Merino), mientras José Luis Arrese controla el partido desde la caída en desgracia de su rival, Serrano Suñer. ${ }^{21}$ FET-JONS es un "partido de partidos» instrumentalizado por el régimen. ${ }^{22}$

La 4. ${ }^{a}$ edición del Manual de campamentos (1948), minada por el tradicionalismo y el catolicismo, refleja el distanciamiento del régimen con el fascismo tras la derrota nazi y su deriva católica y tradicionalista: mayor peso del lobby católico, la Asociación Católica Nacional de Propagandistas (ACNP), en el gobierno de 1945 (Martín Artajo), en detrimento de los falangistas; Ley de Educación Primaria (1945) que entrega la escuela a la Iglesia; Fuero de los Españoles (1945) con una ficticia declaración de derechos; Ley de Sucesión (1947) que instauraba la monarquía. ${ }^{23}$ FETJONS, cada vez más subordinada a Franco, acepta estas y otras disposiciones muy alejadas de su ideología original:24 si la unificación significa el control del partido por las derechas más fascistizadas, la derrota del Eje distancia al régimen del fascismo acercándolo al modelo autoritario que proponían José Calvo Sotelo y los teóricos de la revista Acción Española de Ramiro de Maeztu. ${ }^{25}$

En realidad, ni FET-JONS ni su antecesora (FE-JONS), más allá de vacuas proclamas, dada su promiscuidad ideológica, son capaces de elaborar un discurso propio, revolucionario. Su meta no está en el futuro, sino en el ayer: los gremios medievales, los Reyes Católicos. El hombre nuevo no es sino el caballero medieval o del Siglo de Oro: así lo reflejan los manuales de la asignatura de Formación del Espíritu Nacional, que

\footnotetext{
${ }^{21}$ Sheelagh Ellwood, Historia de Falange Española (Barcelona: Crítica, 2001), 115-156.

22 Ricardo L. Chueca, "FET y de las JONS: la paradójica victoria de un fascismo fracasado», en España bajo el franquismo, ed. Josep Fontana (Barcelona: Crítica, 2000), 60-77.

${ }^{23}$ Tusell, Historia de España en el siglo XX, 164-182, 210-248.

24 Ellwood, Historia de Falange, 157-201.

25 Stanley G. Payne, Franco y José Antonio. El extraño caso del fascismo español (Barcelona: Planeta, 1997), 417, 610 .
} 
FET-JONS tenía en sus manos. ${ }^{26}$ En esta ósmosis juega un papel importante el nacional-catolicismo, una ideología muy versátil que durante el franquismo sirvió para mantener la unidad de los distintos sectores del régimen. ${ }^{27}$

La editorial del FJ es el canal difusor de los manuales de campamentos. El FJ tiene como referentes los Balilla de Mussolini, asociados al mito de la belleza, fortaleza, uniformidad y dinamismo de la juventud italiana, ${ }^{28}$ y, sobre todo, las Hitler Jugend, Juventudes Hitlerianas, que pretenden convertir a los muchachos alemanes en «soldados de una idea», en intérpretes de los deseos de Hitler (principio de autoproducción y autodirección), mientras el Bund Deutscher Mädel, Liga de las Jóvenes Alemanas, desarrolla «objetivos específicamente femeninos»:29 como la Sección Femenina (SF) de Falange creada en 1934. En el Primer Congreso de las Juventudes Europeas (Viena, 1942), José Antonio Elola Olaso, Delegado Nacional del FJ, coincide con Baldur Von Schirach, que lideraba las Hitler Jugend. Aunque el primero, apoyado por el Asesor de Moral y Religión del Frente, Leopoldo Eijo Garay, pretende un mayor protagonismo de la religión, asimila sin dificultad el espíritu totalitario de las Hitler Jugend: liturgias, uniformidad, campamentos... ${ }^{30}$

La prehistoria del FJ está en las poco conocidas organizaciones juveniles de los carlistas (Pelayos), las Juventudes de Acción Popular y de FE-JONS, previas a su unificación. Su protohistoria arranca con los Estatutos de FET-JONS de 4 de agosto de 1937 que crean el cargo de Delegado de Organización Juvenil (OJ), que recae entre 1937 y 1938 en

\footnotetext{
${ }^{26}$ Emilio Castillejo, Mito legitimación y violencia simbólica en los manuales escolares de Historia del franquismo, 1936-1975 (Madrid: UNED-Serie MANES, 2008), 72-79.

${ }^{27}$ Emilio Castillejo, «Educación en el franquismo nacionalcatólico. La negación de la libertad y de la igualdad», en El artículo 27 de la Constitución: Cuaderno de quejas, coords. Manuel de Puelles Benítez y Manuel Menor Currás (Madrid: Morata, 2018), 53-75.

${ }^{28}$ Laura Malvano, «El mito de la juventud a través de la imagen: el fascismo italiano», en Historia de los jóvenes. II. La Edad Contemporánea, dirs. Giovanni Levi y Jean Claude Schmitt (Madrid: Taurus, 1996), 313-346.

${ }^{29}$ Eric Michaud, «"Soldados de una idea”: los jóvenes bajo el Tercer Reich», en Historia de los jóvenes. II. La Edad Contemporánea, dirs. Giovanni Levi y Jean Claude Schmitt (Madrid: Taurus, 1996), 349-379.

30 José Ignacio Cruz Orozco, «Falange, Frente de Juventudes y el nuevo orden europeo. Discrepancias y coincidencias en la política de juventud durante el primer franquismo", Revista de Educación 357 (2012): 515-535.
} 
Mateo Torres Bestard, que inaugura el encuadramiento de sus miembros según edad (Pelayos, Flechas, Cadetes), su organización en Escuadras, Pelotones, Falanges, Centurias, Banderas, Legiones. Bajo el mandato de Sancho Dávila (1938-1940), al contrario que Enrique Sotomayor dispuesto a someterse al régimen, se formulan los doce puntos del Flecha («Para servir a España mi cuerpo ha de ser fuerte y mi alma sana», reza uno de ellos) y se diseña el primer esbozo de campamentos nacionales (Cóbreces en Santander), provinciales (Bergondo en La Coruña, Lago de Sanabria en Zamora...), de «mandos elementales» (Pinseque, Zaragoza) y mandos de campamentos (Fuentes Blancas, Burgos). Julián Pemartín se ocupa de la Formación Nacionalsindicalista y el obispo Leopoldo Eijo-Garay de la asesoría religiosa. ${ }^{31}$

La historia del FJ se inicia con la Ley de 6 de diciembre de 1940, que integra en el FJ al Sindicato Español Universitario (SEU) y la SF, que contará con sus propios mandos (Delegada Nacional, Regidora central) y centros (art. 22). Los grados de encuadramiento reproducen los del sistema educativo con diferenciación por sexo: Pelayos y Margaritas (7 a 9 años), Flechas (10-14 años); Cadetes y Flechas azules (14 a 17 años). Al FJ corresponde formar a sus afiliados, por ejemplo en los campamentos, y el encuadramiento de toda la juventud «para que todos los jóvenes de España sean iniciados en las consignas políticas del Movimiento» a través, por ejemplo, de las colonias de verano. La Ley establece una estructura de mandos jerárquica: el Delegado Nacional, designado por el Mando Nacional del Movimiento (Franco), a propuesta del Secretario General del Movimiento, nombra a los asesores centrales de Educación Física y de Educación Premilitar (art. 16) y a los delegados provinciales (art. 18). La financiación dependerá de aportaciones de Corporaciones, Entidades y particulares y de los presupuestos del Estado (art. 26, 27). ${ }^{32}$ El sometimiento del FJ al Estado es evidente. Con el primer Delegado Nacional, José Antonio Elola Olaso (1941-1956) nombrado por Arrese, continúa la formación de mandos (Academia «José Antonio») y se crean las Falanges Juveniles de Franco (FJF), de carácter voluntario, la elite del sistema. Roberto Cuñat, antiguo scout, es el principal promotor de los campamentos. La victoria aliada en 1945 provoca desinterés hacia

\footnotetext{
31 Sáez, El Frente de Juventudes, 26-78.

32 BOE (7 diciembre 1940), 8.392-8.394.
} 
las FJF y los campamentos en la clase media y su consiguiente proletarización. ${ }^{33}$

La autoría de las publicaciones del FJ y de la SF, salvo si se trata de miembros destacados, queda en el anonimato: en los manuales de campamentos los autores se ocultan tras la Delegación Nacional del FJ. El emisor coincide con el canal, con la edición. El anonimato obedece a una razón ideológica. El Delegado Nacional, Elola Olaso, en el prólogo de las dos ediciones que comparamos ensalza el «ambiente de pureza y anónimo servicio» que debe observarse en el campamento y en el FJ: ${ }^{34}$ el anonimato pone coto al individualismo liberal. Solo he podido identificar uno de esos autores anónimos, Rafael Chaves, que interviene, como veremos, en las páginas de Educación Física del Manual de campamentos de $1948 .{ }^{35}$

\section{CÓDIGOS LINGÜÍSTICOS E IDEOLÓGICOS}

En los manuales de campamentos se identifican diversos códigos lingüístico-ideológicos o sistemas de signos reconocibles por el emisor y el receptor. Favorecen esta diversidad de registros (subculturas políticas), el hecho de ser una obra colectiva editada por el órgano de propaganda de un partido de partidos abierto a las distintas fuerzas de la coalición vencedora en la Guerra Civil, y los cambios de discurso del régimen a lo largo del tiempo.

En el Manual de campamentos de 1943 identificamos el código expresivo falangista: referencias al «modo de ser falangista», la «revolución nacionalsindicalista», la «voluntad de Imperio», las «reivindicaciones de España» (irredentismo), la necesidad de «fortalecer nuestra juventud»... El código militar: referencias a la «moral militar» («Hay que ser soldado»), al

\footnotetext{
${ }_{33}$ Sáez, El Frente de Juventudes, 89-151, 192-205

${ }^{34}$ Manual de campamentos (1943), 7; Manual de campamentos (1948), 10.

35 José Devís, Rodrigo Atienza y Carmen Peiró, «Rafael Chaves Fernández y el predeporte en la Educación Física del franquismo», Citius, Altius, Fortius, Vol. 3-1 (2010): 81-96: Chaves luchó con el ejército republicano pero, merced a sus contactos, escaló puestos en el FJ: profesor en la Escuela Central de Gimnástica del Ejército (Toledo), de la Academia Nacional «José Antonio». Colaboró en revistas: Flechas y Pelayos, Mástil. Publicó libros: Manual de Juegos para la Educación Física (1949), Manual de Educación Física escolar (1958). Fue coautor del Manual de campamentos desde la edición de 1945.
} 
«mando»... El código católico, favorecido por la presencia de destacados miembros del clero en el FJ (Eijo-Garay) y la SF (Pérez de Urbel), que no solo reproduce el lenguaje católico tradicional sobre el «Cuerpo místico cristiano», la naturaleza católica de España, sino que lo fusiona con el falangismo: el «renunciamiento» y la «mortificación» deben «juntar su celo a la mística que respiran los principios de la Falange»; la expresión «Por el Imperio, hacia Ti»: el final de la historia no está en la vacua revolución, sino en la trascendencia.

Hay también un código técnico, racional, adecuado para explicar la financiación, el montaje de tiendas evitando «la pérdida de tiempo», la organización del horario (8-10 horas de descanso, 8 de trabajo, 6-8 de actividades libres), sanidad, alimentación... Y un código pedagógico sobre las actividades al aire libre. Al contrario que la Institución Libre de Enseñanza (ILE), fundada en 1876, hito de la renovación pedagógica en España, que usa la naturaleza como fuente de datos, las excursiones que propone este manual sirven al adoctrinamiento. Todo obedece a la consigna «A la naturaleza no se la sigue: se la vence», y al principio siguiente:

No llevamos a nuestra juventud al campo por «amor a la naturaleza», que es la norma de humanización masónica, sino única y exclusivamente para inculcarles, grabarles a fondo nuestros principios y hacer que adquieran el "modo de ser" falangista. ${ }^{36}$

En esencia, el código falangista parece dominante, si bien convive o se fusiona con otras subculturas. Los cambios en la edición de 1948 son fruto de las nuevas circunstancias internacionales y de la progresiva domesticación de Falange por Franco a través del Ministerio-Secretaría General de FET-JONS ocupado por José Luis Arrese (1941-1945, 19561957) y Raimundo Fernández Cuesta (1951-1956). Quedan incólumes el lenguaje técnico y militar. Pervive el falangista (referencias al vitalismo -«hombres de espíritu joven» frente a «descreídos y pesimistas»- y, ya marginalmente, a la «revolución»), pero cada vez más tamizado por el tradicionalismo y el catolicismo: ahora el «"falangista" " convive con el " "modo de ser" del perfecto caballero español», que es el que "reacciona de un modo viril y enérgico contra todo insulto a Dios y a la Patria».

36 Manual de campamentos (1943), 133-134. Resto información págs. 2, 8, 12, 17-26, 30, 53-67, 110126, 133, 144, 161-173, 188-189, 192-208. Sobre ILE: Diego Carral, «Modesto Bargalló: el arte de educar en la naturaleza», Actas del XVIII Coloquio de Historia de la Educación, Vol. 2 (2015), 481-486. 
A eso queda reducida la energía vital del hombre nuevo. Tradicionalismo también en las referencias a autores del Siglo de Oro (Juan de la Cuesta, Hernando de Talavera), a los Colegios Mayores de la España Imperial...

El código católico se convierte en subcultura dominante. El manual señala la razón: «Debemos formar el tipo de joven católico que necesitan las circunstancias mundiales actuales»: a la altura de 1948, el «joven católico» y el "caballero español» ponen en entredicho al hombre nuevo fascista, aunque todos compartan el deseo de "ahogar el nocivo individualismo propio de teorías poco españolas». Se cita a autores católicos: Manjón, Armentia. Se legitima el pesimismo antropológico católico poco revolucionario-, al advertir sobre «las malas inclinaciones propias de la humana condición, a consecuencia del pecado original». Se cuestionan los campamentos de los Scout o de la «valiente» pero «autoritaria» y «racista» Hitler Jugend, con argumentos eclesiales: carecen del «sentido católico de la vida» y del «fin sobrenatural» que es "lo esencial». Y, sobre todo, "por obligación filial y firme convicción», se señala como «criterio educativo del Frente de Juventudes» la encíclica de Pío XI Divini Illius Magistri, desdiciendo, sin confesarlo, el estatismo educativo de Falange: esta encíclica justifica la subsidiariedad del Estado respecto a la familia y a la Iglesia.

Como señala J. A. Cañabate, la batalla educativa durante el franquismo no la ganó Falange, sino la Iglesia. Pero se olvida que la Iglesia es el Caballo de Troya que actúa en el seno de FET-JONS y del FJ desde sus orígenes a través, por ejemplo, de la Asesoría Religiosa. El subsistema educativo de la Iglesia que analiza Antonio Viñao penetra en lugares en que teóricamente es cuestionado. Penetra su discurso, con la legitimación de la mencionada encíclica. Y penetra sus liturgias: Falange carecía de la liturgia propia de una religión civil, como la escenificada en la Francia jacobina, la Alemania nazi o la Unión Soviética que describe M. Burleigh: pone su uniformización y su marcialidad al servicio de la religión. La clave está en el poder que adquieren en esta los católicos totalistas de que habla Santos Juliá, dispuestos a colaborar con el fascismo para establecer un Estado católico.

El discurso pedagógico (aire libre, motivación positiva, sistema mutuo de enseñanza), como veremos, está condicionado también por el 
catolicismo, poco dado a «consentir con un liberalismo tipo pedagógico, inadmisible para nosotros». ${ }^{37}$

\section{EL MENSAJE: «CIUDADES DE LONA» $Y$ «MODO DE SER»}

En los manuales de campamentos observamos los ingredientes doctrinales y afectivos propios de la cultura política franquista y de sus subculturas: falangista, católica, tradicionalista, militar. Esa cultura y subculturas (siempre del súbdito) no pueden desentenderse del control de los cuerpos que impone el campamento a nivel colectivo (los campamentos son "ciudades de lona») e individual: a través de dispositivos disciplinarios y actividades, los acampados adquieren un «modo de ser».

\section{Práctica gubernamental en las «Ciudades de lona», colectivo orgánico y prefiguración del Estado franquista}

Ramón Serrano Suñer definió la España de Franco como un «Estado campamental». ${ }^{38}$ En sentido inverso, para el Manual de campamentos (1943), estos prefiguran el orden social y político que pretende Falange en la «Nueva España»:

Los campamentos del Frente de Juventudes son, en pequeño, auténticas «ciudades de lona», que funcionan en régimen íntegramente Nacionalsindicalista. En este sentido, no son más que un anticipo de lo que queremos que llegue a ser el pueblo, la ciudad, la nación futura. ${ }^{39}$

Lo prefigura por su estructura orgánica y por la práctica gubernamental. En primer lugar, el campamento funciona como un microcosmos

\footnotetext{
37 Manual de campamentos (1948), 17-23, 24-28, 30-32, 58, 69, 72, 97. José A. Cañabate, «La pugna entre la Iglesia católica y el Frente de Juventudes en el ámbito educativo. Referencias internacionales, antecedentes y trayectoria general durante el primer franquismo", Historia de la Educación 2223 (2003-2004): 105-121. Antonio Viñao, Escuela para todos. Educación y modernidad en la España del siglo XX (Madrid: Marcial Pons, 2004), 201-210. M. Burleigh, Poder terrenal. Religión y política en Europa. De la revolución francesa a la I Guerra Mundial (Madrid: Taurus, 2005); Michael Burleigh, Causas Sagradas. Religión y política en Europa. De la Primera Guerra Mundial al terrorismo islamista (Madrid: Taurus, 2006). Santos Juliá, Historia de las dos Españas (Madrid: Taurus, 2004), 297-305.

38 Alberto Reig Tapia, «Aproximación a la teoría del caudillaje», Revista de Estudios Políticos (Nueva Época) 69 (1990): 75.

39 Manual de campamentos (1943), 12.
} 
orgánico, como un cuerpo, al que se subordinan los cuerpos de los acampados. A tal fin, los cuerpos de los muchachos son orientados en el tiempo, regulado desde Diana a la hora de Silencio, y en el espacio tanto interior (las mesas del comedor deben formar un conjunto presidido por la mesa de los Jefes) como exterior: la avenida principal llevará el nombre de Franco, la plaza central, el de J. A. Primo de Rivera. Se rechaza la suma inorgánica de individuos, el individualismo liberal (premios individuales) y el gregarismo: se prohíben las colas en el reparto de comida para evitar «una sensación de multitud gregaria, que es precisamente lo que se quiere evitar». Es el miedo que la corte literaria de José Antonio Primo de Rivera aprendió en La rebelión de las masas de Ortega y Gasset. La alternativa es el «encuadramiento orgánico» de los acampados en escuadras, pelotones, falanges, centurias de Flechas y Cadetes (no hay campamentos de Pelayos), que prefiguran los cuerpos intermedios entre el individuo y el Estado de la sociedad orgánica propios de los regímenes fascistas y autoritarios de derechas.

Según el ideal joseantoniano, el campamento integra a "camaradas de las diversas regiones de España» (se prefieren los campamentos interprovinciales) en una "perfecta unión de clases»: se rechaza expresamente el clasismo; las escuadras deben mezclar muchachos de distinto origen social. En cualquier caso, al margen de pretensiones revolucionarias, el campamento (lo mismo que el Estado orgánico) reproduce las clases sociales: el manual insiste en que, no siendo una institución benéfica ni gratuita, cada cual debe hacer aportaciones según sus posibilidades.

En segundo lugar, el campamento no es una polis (depende de autoridades del exterior), sino una «ciudad de lona» que prefigura al Nuevo Estado por la práctica gubernamental, por contar con instrumentos similares de control de la colectividad. Posee, primero, un cerebro, el Jefe de Campamento, cuya «mirada vigilante todo lo ve y a todo pone remedio». Dependiente del Jefe de Departamento Provincial de Campamentos, está dotado de carisma y cualidades morales: «autoridad», «dotes de organizador», «es el que más sabe» el que «todo lo ve y a todo pone remedio», se hará "respetar como Jefe único» y "querer como un padre»: un panóptico inspirado en el principio del caudillaje. Según A. Reig Tapia, este principio fue apuntado por J. A. Primo de Rivera (Jefatura como «sacrificio» y «servicio») y desarrollado en los años cuarenta por Francisco Javier Conde («mando», carisma, paternalismo, ejemplaridad...) 
que se inspira en Carl Schmitt, el Führerprinzip, el tradicionalismo, el catolicismo, el militarismo. En realidad, toda la extrema derecha comparte ideales semejantes: Ramiro de Maeztu en su Defensa de la Hispanidad sostiene también el ideal de servicio y jerarquía como garantía de eficacia. Al Jefe de Campamento, que mantiene la «unidad de mando», acompaña «un conjunto orgánico» de mandos, jerarquizado, con funciones definidas «para evitar que se diluyan las responsabilidades»: Capellán, y Jefes de Formación, Intendencia, Sanidad, Educación Premilitar, Educación Física, Servicios Técnicos, Administración, Orden y Policía.

Segundo, como el Estado, el campamento cuenta con un corpus legislativo (reglamento), medios de financiación, medios coercitivos (guardias) y unos saberes técnicos, muy desarrollados en el manual, sobre administración, contabilidad y, lo que más interesa aquí, sobre aspectos biopolíticos: saneamiento (baño, duchas, letrinas, desagües, pudridero); servicios sanitarios, botiquín (instrumental, medicinas); suministro, almacenamiento y distribución de víveres, cálculo de calorías, grasas, albúmina que se debe consumir, régimen alimenticio, higiene en el consumo... Se apuntala así la transición sanitaria (frenazo de enfermedades infecciosas) que, según Elena Robles, se completa en España en los años cincuenta del siglo pasado.

Tercero, afirma educar en una ideología «íntegramente Nacionalsindicalista», aunque sabemos que confluyen otros códigos: católico, militar... La propaganda (radio, prensa, revistas) respetará la ortodoxia; en correos habrá censura (no se respeta la inviolabilidad de correspondencia), supuestamente para «evitar todo falseamiento de la realidad que dé lugar a preocupaciones injustificadas de los familiares». Cuarto, como el Estado franquista, recurre a mecanismos de evasión, crea espacios afectivos como el Fuego de Campamento para la distensión y las «expansiones más alegres»: es el único lugar en que se requiere la «colaboración espontánea de los acampados» (competiciones entre las escuadras para contar historias, cantar) y en que «incluso los Mandos, despojados momentáneamente de su investidura jerárquica, se confunden con los muchachos para participar en su diversión». Quinto, como el Estado, el campamento debe demostrar su eficacia: en la clausura cabe "apreciar el resultado de la labor efectuada sobre nuestros pequeños camaradas» 
a través de exhibiciones gimnásticas, desfiles de Cadetes si están «en condiciones de efectuarlos con verdadera marcialidad y vistosidad».40

La «ciudad de lona» que describe la edición de 1948 no experimenta cambios en lo relativo a servicios sanitarios, financiación, propaganda, censura, escuadras y "conjunto orgánico» de mandos que se distinguen por sus «dotes naturales», alternativa al gregarismo y al individualismo roussoniano, la «rivalidad malsana» (premios individuales), los «bandos» (prefigura de los partidos políticos). Pero introduce dos grandes novedades que recuerdan la evolución del propio régimen:

En primer lugar, disminuye la fe revolucionaria y aumenta la resignación. Se sigue simulando «la unión de clases». Pero, además de afirmar implícitamente la función reproductora del campamento (los acampados aportarán según sus posibles), se justifica explícitamente -es la novedadla «estratificación social en las escuadras» para prevenir el «contacto a edad prematura con muchachos de distinta clase social» y el establecimiento con «carácter circunstancial» de turnos de aprendices, de colegios religiosos..., medidas -reconoce- «que podrían parecer "clasistas"». La convivencia de clases, como la revolución, queda pendiente. Se reconoce el porqué: «la justa prevención que pueden tener las familias en contra de la prematura convivencia de sus hijos con otros muchachos de distinto nivel cultural» (eufemismo de clase social): esas prevenciones, dada la proletarización progresiva del FJ, según Sáez Marín, eran un hecho. El campamento no sirve a la revolución, sino a la estrategia de distinción de que habló Bourdieu: los padres con posibles marcan distancias con los desposeídos.

En segundo lugar, un mayor peso de lo católico en la práctica gubernamental. Porque la finalidad temporal del campamento, educar al joven español "en su totalidad "espíritu unido al cuerpo" ", solo se entiende si está «basada en lo sobrenatural». Porque el objetivo del encuadramiento es «completar a la familia en la importantísima misión de integrar al joven en el medio social»: es el principio de subsidiariedad

\footnotetext{
40 Manual de campamentos (1943), 12, 27, 30-33, 37-38, 42, 45, 66, 77, 135, 141-143, 178-184, 196. José Ortega y Gasset, La rebelión de las masas (Madrid: Austral, 2016), 191; Reig, «Aproximación a la teoría del caudillaje», 69; Ramiro de Maeztu, Defensa de la Hispanidad (Madrid: Gráfica Universal Evaristo San Miguel, 1935), 287-304; José Luis Villacañas, Ramiro de Maeztu y el ideal de la burguesía en España (Madrid: Espasa, 2000), 373; Elena Robles González, Fernando García Benavides, y Josep Bernabeu Mestre, «La transición sanitaria en España desde 1900 a 1990», Revista Española de Salud Pública 70, n. ${ }^{\circ} 2$ (1996): 221-233.
} 
(primacía de la familia y de la Iglesia frente al Estado) de la encíclica Divini Illius Magistri que legitima este manual. Porque la seña de identidad del campamento del FJ frente a otros modelos (Scouts, Exploradores) está en su sentido católico: su objetivo es «educar a nuestras juventudes en el temor de Dios y en el amor a España». Por prever los riesgos que puede acarrear el escuadrismo para la moral sexual, seña de identidad de la Iglesia: «desviaciones que pueden rozar peligrosamente -sobre todo en los mayores- el vicio». El manual propone evitar el «desnudismo innecesario», las tiendas de campaña bipersonales, que se dejen demasiadas horas de holganza: la presencia constante del Capellán, desde su propio panóptico, "proporciona la ayuda que necesita todo joven $\mathrm{u}$ hombre para vencerse a sí mismo».

Si según el manual de 1943 el Jefe de Campamento preside un panóptico, compatible con el del Capellán, el editado en 1948, sin excluir la «paternal y constante, aunque lejana vigilancia», habla de «sentido corporativo», «sentido de hermandad» del escuadrismo. Evolución semejante experimenta el sindicato único del régimen: según Ángela Cenarro, el corporativismo católico (colaboración de patronos y obreros), acaba imponiéndose frente al verticalismo de Falange, que pretendía la regulación de las relaciones laborales por el Estado anunciada en el Fuero del Trabajo (1938). El catolicismo impone también un nuevo modelo pedagógico, la "cooperación activa» y la autodirección, cuyo objetivo es crear «personalidades al estilo español tradicional», respetando las iniciativas de los acampados a través del sistema mutuo... sin caer en «tendencias socializantes de nivelación hacia abajo», en el despotismo y centralismo absorbente (estatalista), ni en el liberalismo pedagógico, el selfgovernment anglosajón. Un modelo que «cree en el HOMBRE más que en el sistema»:

Dadles una misión concreta y bien definida; fijadles en términos bien claros su responsabilidad y atribuciones, concededles iniciativa y un generoso margen de confianza; veréis el enorme provecho que de ellos puede sacarse y de qué manera puede suplirse en muchos casos la falta momentánea de colaboradores mayores. Cuidad tan solo de que en los momentos críticos haya -a distancia- un jefe superior que sepa guiar y encauzar. ${ }^{41}$

\footnotetext{
${ }^{41}$ Manual de campamentos (1948), 64. Resto información: 19, 24-28, 33-50, 57-78, 93-110. Á. Cena-
} rro, «Encuadramiento y consenso en la obra del Movimiento: mujeres, jóvenes y obreros», en 
Para Sáez Marín, la autodirección se inspira en la selbtsführung, la mencionada autoproducción y autodirección nazis: ${ }^{42}$ en cambio, el manual que comentamos cita como fuentes de inspiración a Fray Hernando de Talavera, Juan de la Cuesta, Ángel Manjón. La autodirección, una interiorización de normas que no excluye la vigilancia, no es sino el humanismo cristiano, inaugurado por las encíclicas Rerum Novarum (1891) o Divini Illius Magistri (1929) y sostenido por Ramón Ruiz Amado, Ángel Herrera, que pretende una educación integral que no olvide el fin sobrenatural del hombre. ${ }^{43}$ Va asociado a un método didáctico activo, fraternal y participativo, puesto en práctica antes de la Guerra Civil no solo en la enseñanza reglada (Padre Manjón), sino en los Círculos de Estudios del Padre Azpiazu o el escultismo católico. ${ }^{44}$ Es el método que recupera el Frete de Juventudes, ahora muy condicionado por el catolicismo, que, como veremos, tiene una gran repercusión en la normalización de los cuerpos.

\section{El «modo de ser» falangista: normalización de los individuos a través de las actividades de los campamentos}

La finalidad esencial de la práctica gubernamental que acabamos de ver es garantizar la unidad del todo orgánico. Las actividades desarrolladas en el campamento, además de inculcar dogmas y afectos, una cultura política, actúan directamente sobre el cuerpo de los individuos. Elola Olaso en las palabras preliminares del Manual de campamentos (1943) deja claro el tipo de cuerpos que pretende formar: hombres con «nervio», «duros, recios e infatigables» (el vitalismo del «modo de ser» joseantoniano), que hagan resurgir la Patria tras el «decaimiento de la raza, después de siglos de dispersión y de pereza» (es la idea de Ramiro de Maeztu sobre el resurgir de España después del decaimiento que localiza en

Falange. Las culturas políticas del fascismo en la España de Franco (1936-1975), ed. Miguel Á. Ruiz Carnicer (Zaragoza: Institución Fernando el Católico-Diputación de Zaragoza, 2013), 205-208. Sáez, El Frente de Juventudes, 435-438.

42 Sáez, El Frente de Juventudes, 350-356.

43 Alfonso Capitán Díaz, «Humanismo pedagógico en la España Contemporánea, 1875-1951», Revista Española de Pedagogía 223 (2002): 461-480.

${ }_{44}$ Pere Fullana y Feliciano Montero, «Los modelos educativos juveniles del movimiento católico en España (1868-1968», Historia de la Educación 22-23 (2003-2004): 33-51. 
1700), «hombres con resuelta voluntad de vencer, de crecer y multiplicarse, de resurgir»: son las teorías eugenésicas de Antonio Vallejo Nájera basadas, más que en la biología, en planteamientos conductistas y purificadores para corregir los daños derivados del liberalismo y del marxismo. Como señala Marta Mauri, esa normalización de los cuerpos no es ajena a objetivos económicos (formar trabajadores), militares (formar soldados) y políticos (perpetuar el régimen de Franco). Dureza, nervio, masculinidad... apuntan a la imposición en los cuerpos de la línea recta, vertical. La resignación y mansedumbre que impone la Iglesia tiene más que ver con líneas sinuosas. Líneas sinuosas deben describir también los cuerpos femeninos de la SF que, como afirman los trabajos de Elena Ramírez o Francisco Javier Martínez Cuesta, aunque comparte principios como la disciplina y las rutinas, no tiene campamentos, cuyo modelo es el cuartel, sino albergues, cuyo modelo es el hogar; no realiza marchas, sino excursiones; introduce la música para desarrollar valores femeninos como la religiosidad y la sensibilidad.

La «formación de la personalidad» (masculina) del acampado debe acomodarse a estos postulados, mitad contrarrevolucionarios, mitad fascistas. Los ingredientes doctrinales y afectivos (amor patrio, camaradería, carisma del Jefe) de la cultura política que se pretende inculcar son inseparables del control de los cuerpos: el súbdito queda desposeído del cuerpo en favor del todo orgánico. Con razón señala Marta Mauri que, para el fascismo, el cuerpo no es propiedad del individuo, sino de la Patria o del Estado. Apunto algunas formas de desposesión. Hemos citado ya la apropiación del cuerpo del acampado en el tiempo (horarios, ocupación constante) y el espacio, un espacio compartimentado donde debe moverse. Hemos hablado de la necesidad vencer la naturaleza (negación del cuerpo de los individuos) y del encuadramiento (afirmación del todo orgánico). El manual habla además de tácticas pedagógicas como el estímulo (potenciando el papel de escuadras y pelotones) y la emulación: competiciones, puntuación por tiendas, recompensas honoríficas, castigos que, en cualquier caso, no pueden ser vejatorios. Habla de uniformización. El uniforme es, según Marta Mauri, una manera de homogeneizar y normalizar 
a los individuos. Según Lazar Koprinarov, el uniforme deshumaniza a sus portadores, atándolos a normas de comportamiento que los cambian y jerarquizan. Se suele olvidar que, además, el uniforme oculta las clases sociales: produce una imagen armoniosa de la sociedad.

El manual impone además el automatismo, margina la razón y la conciencia, que es la manera, como señalaban Mauss o Bourdieu, de naturalizar el habitus. Por ello, las normas en el campamento deben cumplirse «sin réplica». Los movimientos deben obedecer al imperativo de una voz exterior, como reflejos condicionados: al toque de Diana, "se levanta inmediatamente todo el mundo»; en la Consagración, al toque de cornetín, «deberán arrodillarse todos los acampados que se encuentren dentro del radio de visibilidad de la Capilla, poniéndose en posición de "Firmes" todos los demás»; con el toque de Fajina, los acampados, «al mando de sus Jefes, se dirigen al comedor» $\mathrm{y}$ "cada pelotón se coloca en el sitio previamente designado»; al arriar bandera, tras entonar el Cara al Sol, «se traslada toda la formación ante la Cruz de los Caídos. Puestos "Firmes", se toca el Toque de Oración y se rezan las oraciones reglamentarias»; ante el mando se saluda "con estilo falangista». ${ }^{45}$

El Manual de campamentos de 1948 conserva las palabras preliminares de Elola Olaso. Pero, como sabemos, pierde espíritu revolucionario en favor del tradicionalismo y de la religiosidad. El «modo de ser» falangista se identifica con el caballero español, «monje»y «soldado». Se exige la boina roja en las guardias, el símbolo tradicionalista, que no se mencionaba en el manual de 1943, quizás por olvido, quizás para

\footnotetext{
45 Manual de campamentos (1943), 6-8, 11-12, 133-157. Maeztu, Defensa de la Hispanidad, 12; Ricardo Campos, «Psiquiatría, raza y represión en el primer franquismo: Antonio Vallejo Nágera», en Los intelectuales y la dictadura franquista. Cultura y poder en España de 1939 a 1975, ed. Antonio Altarrabia et alt. (Madrid: Editorial Pablo Iglesias, 2014), 19-45. Sobre Educación Física: Marta Mauri Medrano, «El cuerpo juvenil sano como símbolo político del fascismo. La normalización de los cuerpos a través del discurso médico del fascismo», Riphe. Revista Iberoamericana. Patrimonio Histórico-Educativo Vol 2-3 (2016): 117-128. Sobre uniforme: Mauri, «Mens sana in corpore sano...», 385; Lazar Koprinarov, «La guerra en la paz: el uniforme militar y los preparativos antropológicos para la guerra», Thémata. Revista de Filosofía 48 (2013): 143-151. Sobre objetivos económicos, militares y políticos del control corporal: Mauri, «Disciplinar el cuerpo para militarizar a la juventud, 100-101. Sobre formación en la SF: Elena Ramírez Rico, César Fernández Quevedo y Emilia Fernández García, «Las publicaciones sobre la organización del Frente de Juventudes (1940-1961). Adiestramiento de las mujeres en las actividades en la naturaleza», Historia y comunicación social 23 (2018): 257272; Francisco Javier Martínez Cuesta, «"Estaréis alegres en nuestra compañía”. Las actividades en los campamentos de la Sección Femenina (1942-1953)», El Futuro del Pasado 9 (2018): 61-84.
} 
salvaguardar los principios revolucionarios más puros. La alerta sobre moral sexual («desviaciones», «vicio») ya no aparece solo en las páginas de Formación Religiosa, sino en la explicación del escuadrismo. El humanismo cristiano añade nuevos conceptos pedagógicos al estímulo y la emulación: «motivación positiva» (la prohibición de fumar no es total: «es más hombre quien sabe dominarse»); autodirección (concurso de reglamentos de tiendas); «autocastigos» («el culpable» propondrá «la sanción que cree merecer» evitando un motivo de rencor hacia el mando); posibilidad de realizar «Mi actividad preferida» (manualidades, deporte). Todo ello permite una mayor distensión: los cuerpos podrán dibujar líneas oblicuas o quebradas. Pero ello no significa el final de la normalización, incluso al contrario: el que da órdenes no está solo fuera (el panóptico), sino dentro de los cuerpos. Nadie sabe más de introspección, de interiorización de normas, que la Iglesia. Interiorización que, curiosamente, ha actualizado el nuevo capitalismo que, como señala Remedios Zafra, exige iniciativa, «entusiasmo», a cambio de «un pago afectivo»e «inmaterial».46

\section{Educación Premilitar: uniformidad, verticalidad y automatismo}

Según José Ignacio Cruz, Alfonso Pérez Viñeta, militar africanista y secretario nacional del FJ, impone en esa organización y en los campamentos una fuerte impronta castrense, que se va relajando tras la Segunda Guerra Mundial. La Educación Premilitar, propuesta ya por los «27 puntos» de Falange, la norma programática de FE-JONS (1934), es, según la edición de 1943, responsabilidad del Jefe de Formación Premilitar. Refuerza la cultura del súbdito a través de los afectos («Honor», «Moral militar») y múltiples formas de normalización del cuerpo. Regula los movimientos de los mandos (gesto correcto, resolver con calma, ejecutar sin titubeos) y de los acampados: guardias con mosquetones de los Cadetes, guardias sin armas diurnas de los Flechas. Encuadra militarmente a los acampados según su estatura y jerarquía: Jefes de Escuadra, Pelotón, Falange y Centuria. Inculca «el hábito de la disciplina cotidiana», la «rigurosa seriedad en las formaciones», la uniformidad, el sometimiento a «pequeñas molestias» (frío, calor...), para «endurecer

\footnotetext{
46 Manual de campamentos (1948), 50-56, 75-78, 245-292. Remedios Zafra, El entusiasmo (Barcelona: Anagrama, 2017), 21.
} 
y probar el futuro soldado»: recordemos la finalidad última de conservar y perpetuar el régimen. La obediencia exige el automatismo en movimientos. La rectitud y verticalidad es la actitud dominante en las posiciones individuales (pasos, giros, saludos) y formaciones colectivas en orden cerrado (alineaciones, evoluciones) y abierto (para Cadetes). ${ }^{47} \mathrm{La}$ edición de 1948 conserva la misma filosofía, pero, más escéptico con la revolución, abre la posibilidad de clasificar los cuerpos según las clases sociales en escuadras y campamentos distintos. ${ }^{48}$

\section{Formación Nacionalsindicalista: adoctrinamiento, adiestramiento y tensión}

La Formación Nacionalsindicalista, que según el Manual de campamentos de 1943 corresponde al Jefe de Formación y Cultura, afecta al intelecto (habla de «orden nuevo», «revolución», «reivindicaciones de España»), a los afectos (inculca patriotismo, alegría, voluntad, ánimo) y a la disciplina del cuerpo. Porque el método didáctico del Manual del acampado, el catecismo, requiere un adiestramiento mecánico basado en la repetición, no en la reflexión. Porque ciertas prácticas de Formación Nacionalsindicalista exigen una pose (al izar banderas) o una situación de tensión e «intranquilidad» en los acampados: en cualquier momento se les puede exigir repetir consignas grabadas «insensiblemente en la mente de los muchachos». El propio contenido de éstas guarda a veces relación con el dominio del cuerpo: «A la naturaleza no se la sigue: se la vence»; «No queremos hombres fuertes para admirare el músculo, sino para servir a la idea de la Revolución»; «La única arma de las juventudes revolucionarias frente al capitalismo, la burguesía y el marxismo, es su fuerza»; «Las juventudes constituyen el nervio de las grandes Revoluciones». ${ }^{49}$

\footnotetext{
47 Manual de campamentos, 1943, 192-208. José Ignacio Cruz, «Mientras España siga sin gustarnos, no podemos tener vacaciones. Una aproximación a los campamentos del Frente de Juventudes en la provincia de Valencia (1937-1955)», en Pedagogia. Pensament, política i pràctica. Lectures històriques en la societat valenciana contemporània, eds. Alejandro Mayordomo Pérez y Andrés Payà Rico (Valencia: Tirant Humanidades, 2019), 66-67.

48 Manual de campamentos (1948), 305-318.

49 Manual de campamentos (1943),161-179.
} 
El Manual de campamentos de 1948 impone cambios desde el punto de vista doctrinal, resultado de la desfascistización del régimen. La actividad no se denomina Formación Nacionalsindicalista, sino Formación Política. No queda asomo de las «reivindicaciones españolas», del irredentismo. Sin desaparecer del todo, en las consignas pierde peso la «revolución nacionalsindicalista» en favor de una imprecisa justicia social ( «El falangista debe ser católico ejemplar, español insuperable y apasionado por la justicia social») y del nacionalcatolicismo: la consigna que rezaba en 1943 «No queremos hombres fuertes para admirar el músculo, sino para servir a la idea de la Revolución» se convierte en 1948 en «No queremos hombres fuertes para admirar el músculo, sino para servir a Dios y a España»; la que rezaba «La Revolución no es un tópico, es un arma», en "¿Viva España? Exigimos más: ¡Arriba España!»; la que rezaba «La única arma de las juventudes revolucionarias frente al capitalismo, la burguesía y el marxismo, es su fuerza», en "Luchamos por la Patria, el Pan y la Justicia»... Para justificar la visión armoniosa del corporativismo se recurre al lenguaje eclesial:

Si en los turnos de Aprendices hay que vencer y superar la tendencia a la lucha de clases y a la asimilación de fáciles doctrinas demagógicas, en los de Escolares - particularmente donde se encuentran muchachos de clases más acomodadas- hay que combatir la inclinación al egoísmo. ${ }^{50}$

En todo caso, no hay cambios en los objetivos emocionales («ganar para España y la Falange la voluntad y el ánimo»), el sexismo («El miedo no es condición de hombres, sino de niñas tontas») y en el método mecánico de repetir consignas, la voluntad de vencer la naturaleza, de normalizar los cuerpos de los que se espera una respuesta, un movimiento o una posición concreta.

\section{Formación religiosa: control de las pulsiones, mansedumbre,} líneas sinuosas

Según el Manual de campamentos de 1943, al Capellán, responsable de la Formación Religiosa, corresponde la «santificación de las almas» y atender los «problemas de índole moral y psicológico» de los muchachos.

50 Manual de campamentos (1948), 286. Resto de información, 271-292. 
Ello requiere una domesticación de los cuerpos. Porque los actos religiosos del campamento exigen una actitud corporal: escuchar la Santa Misa -voluntaria- «con fervor», recogimiento (se impone la línea sinuosa). Por el aprendizaje memorístico, repetitivo, de la oración reglamentaria. Porque el Capellán inculca el «espíritu de renunciamiento y mortificación» que concuerda con la mística de Falange (y con las privaciones que impone el medio social), detecta las «pasiones» y "hábitos perniciosos» (referencia implícita a la masturbación y las prácticas homosexuales) y vigila la «moralidad general», que no impere un «desnudismo excesivo e innecesario», que los chistes sean «limpios y sin doblez». El Capellán al final del periodo de campamento deberá remitir al Jefe de Campamento un informe con todo el material recogido sobre el «abandono religioso o moral» de los acampados «para que, con todo cuidado, procuren su enmienda»: el Capellán tiene su propio panóptico. ${ }^{51}$

La edición de 1948 desarrolla más detalladamente las funciones del Capellán, evidenciando mejor su potestad en el control de los cuerpos, al que no es ajeno el consabido automatismo. En la misa diaria, siempre voluntaria, a cada toque de corneta corresponde una posición: toque de "Atención» (de rodillas); toque de «Descanso» (sentado o de pie). La comunión debe hacerse de rodillas, salvo excepciones; la bendición de la mesa, de pie y siguiendo una fórmula: "En el nombre del Padre, y del Hijo y del Espíritu Santo. Amén” (No se añade más)»: "Y se sientan». Si hacemos caso a Cruz Orozco, también en Mandos, revista oficial del FJ, menudean estos años las consultas a la Asesoría Religiosa del FJ sobre la forma de santiguarse, de hacer la genuflexión... Además, al Capellán no solo corresponde la formación moral, sino la formación intelectual: los acampados deberán memorizar máximas religiosas (no citadas en la edición de 1943), un discurso que compite con el del Jefe de Formación. ${ }^{52}$

\section{Educación Física: rectitud de las tablas, oblicuidad en el predeporte}

La Educación Física es, en principio, signo de modernidad. Un decreto de Eduardo Chao durante la I República en 1873 introdujo la

\footnotetext{
${ }^{51}$ Manual de campamentos (1943), 187-192.

52 Manual de campamentos (1948), 293-303. José Ignacio Cruz Orozco, «Nacionalcatolicismo en el Nacionalsindicalismo. Algunos ejemplos del Frente de Juventudes», Historia de la Educación 22-23 (2003-2004), 421-429.
} 
Gimnástica en la segunda enseñanza. ${ }^{53}$ La ILE favoreció una educación en libertad (derechos del cuerpo, coeducación, juegos), contraria al dogmatismo del cuartel o del convento, ${ }^{54}$ anunciando los objetivos competenciales del currículo actual. ${ }^{55}$ Los gobiernos conservadores de la Restauración o eliminan la asignatura (Proyecto de Ley de Bases de Instrucción Pública de 1876 del Conde de Toreno), la convierten en optativa (plan de segunda enseñanza de 1899 de Luis Pidal y Mon), o la relegan al horario de tarde (plan de bachillerato de 1900 de Antonio García Alix). ${ }^{56}$ Los liberales, más próximos a la ILE, la hacen obligatoria: planes de segunda enseñanza de Joaquín López Puigcerver de 1894 y de Germán Gamazo de 1898. ${ }^{57}$ El fascismo también favorece la Educación Física, aunque por motivos muy distintos: por el culto a la fuerza del uomo nuovo mussoliniano o del homen novo de Salazar ${ }^{58}$, asociado en la España de Franco a la imagen del «monje-soldado» ideado, entre otros, por Giménez Caballero, ${ }^{59}$ por ser un medio propagandístico, ${ }^{60}$ y por un prurito de modernidad: estando bajo el control de FET-JONS, es vista con malos ojos por la Iglesia por razones de moral sexual.61

\footnotetext{
${ }_{53}$ Colección Legislativa de España, Vol. 110, Segunda Parte, (1873), 1.443-1444.

${ }_{54}$ María E. Martínez Gorroño y J. L. Hernández Álvarez, «La Institución Libre de Enseñanza y Pierre de Coubertin: la educación física para una educación en libertad», Revista Internacional de Medicina y Ciencias de la Actividad Física y del Deporte Vol. 14, n. 54 (2014): 243-263.
}

55 José Luis Felipe Maso, «La Institución Libre de Enseñanza: sus principios pedagógicos innovadores y su presencia en el currículo de la Educación Física actual. El primer centro docente español que utilizó el deporte como elemento educativo», Citius, Altius, Fortius Vol. 7, n. ${ }^{\circ} 2$ (2014): 57-82.

${ }_{56}$ Respectivamente: Colección Legislativa de España, Vol. 117 (1876), 874-878; Colección Legislativa de España, Vol. 3 (1899), 526-530; Colección Legislativa de España, Vol. 6 (1900), 528-535.

57 Respectivamente: Colección Legislativa de España, Vol. 155 (1894), 624-636; Colección Legislativa de España, Vol. 2 (1898), 244-255.

58 Juan Antonio Simón, «Deporte y totalitarismo», Hispania Nova 17 (2019): 224-234; Daniele Serapilglia, "L'uomo nuovo. Sport e corporativismo tra fascismo e cattolicesimo italiano nell'estado novo portoghese tra le due guerre», Hispania Nova 17 (2019): 235-269.

59 Teresa González Aja, «Monje y soldado. La imagen masculina durante el franquismo», Revista Internacional de Ciencias del Deporte Vol. 1 (2005): 64-83.

${ }^{60}$ Alejandro Viuda-Serrano, «Héroes de papel: el deporte y la prensa como herramientas de propaganda política del fascismo y el franquismo. Una perspectiva histórica comparada», Historia y Comunicación Social Vol. 17 (2012): 41-68.

${ }^{61}$ Juan Antonio Simón, «El deporte en el NO-DO durante el primer franquismo, 1943-1951», Hispania Nova 17 (2019): 341-371. 
A falta de referentes propios, la Educación Física española miró desde el siglo XIX al exterior ${ }^{62}$, abriéndose una guerra entre los métodos de la ILE y de militares como el general José Villalba, artífice de la Escuela Central de Gimnasia (1919-1936). ${ }^{63}$ El FJ, dada su impronta castrense, conecta con referentes militares (Amorós, Villalba), nacionalistas (Jahn), los inclinados a la geometría (H. Ling), la fisiología («perfeccionar la raza»), y rechaza el naturalismo de la ILE y la expresividad. ${ }^{64}$ El sexo débil tuvo su propio referente, el método Ling de Elizabeth Björksten, una gimnasia menos rígida. ${ }^{65}$

Efectivamente, según el Manual de campamentos (1943), la Educación Física, responsabilidad del Jefe de Educación Física, debe «fortalecer la raza» y vigilar la higiene. Y, frente a la " "humanización" masónica» (ILE), que busca un mero desarrollo físico, "contribuye "per se" a la formación espiritual de nuestros pequeños camaradas», al «modo de ser» falangista: las competiciones liman «toda inclinación morbosa y egoísta», favorecen la camaradería y la disciplina. En las clases de las mañanas los acampados deberán aprender al menos tres tablas, reglamentos de los juegos y deportes, y los inconvenientes derivados de su mala práctica. Por las tardes harán competiciones, otorgándose premios colectivos. En la fiesta de clausura los Cadetes harán demostraciones de las tablas, los Flechas, de carreras, natación, tracción de cuerda... En esencia, masculinidad (fuerza, disciplina, geometría, rectitud) frente a expresividad; uniformización frente a individuo, conectando con la cultura política del súbdito. ${ }^{66}$

En la edición de 1948 permanecen las tablas, la preocupación higienista, la uniformización. Pero ahora tienen mucho más peso los juegos educativos que, según el Padre Manjón, ayudan a distraer el espíritu, a formar caracteres «dignos y nobles». Rafael Chaves, como hemos

62 Carmen Pérez Ramírez, «Evolución histórica de la Educación Física», Apunts: Educación Física y Deportes 33 (1993): 24-38: detalla distintos modelos de Educación Física desde el siglo XVIII.

${ }_{63}$ Xavier Torrebadella Flix, «La Educación Física Comparada en España (1806-1936)», Historia Social y de la Educación Vol. 3, n. ${ }^{\circ} 1$ (2014): 25-53.

${ }^{64}$ Marta Mauri Medrano, «Mens sana in corpore sano...», 387.

${ }^{65}$ Teresa Rabazas Romero, «La educación física del Magisterio femenino en el franquismo», Revista Complutense de Educación Vol. 11, n. ${ }^{\circ} 2$ (2000): 167-198.

${ }_{66}$ Manual de campamentos (1943), 133-134, 208-218. 
anunciado, incorpora en el manual numerosos juegos «predeportivos» (conducen a la práctica del deporte), de inspiración popular (balón limitado o el balón semicírculo), europea (balón-tiro o el korfbal), o de invención propia (balón-torre, balón al bolo). Estos juegos, sin olvidar la formación del carácter (deber, jerarquía, valor, prudencia) ni el moralismo sexual (encauzan las «energías sobrantes, evitando se consuman en prácticas que pudieran engendrar hábitos perniciosos»), educan los afectos: camaradería, caballerosidad, alegría. Dejan más espacio a la improvisación, a la oblicuidad. Pierden el estatismo y rigidez tradicionales, no por influencia de la ILE (Chaves afirma que en su momento desconocía la labor de los institucionistas en la recuperación de esos juegos), sino del humanismo pedagógico cristiano del Padre Manjón, que Almond y Verba no tendrían quizás dificultad en definir como cultura del súbdito participante. ${ }^{67}$

\section{Actividades culturales y recreativas: simulación de libertad}

Este manual añade un capítulo sobre actividades culturales y recreativas: Trabajos Manuales (madera, marquetería, modelado), Aeromodelismo que, lo mismo que los actos de inauguración y clausura y el Fuego de Campamento que en el manual de 1943 eran responsabilidad del jefe de Formación Nacionalsindicalista, son dirigidas por el Jefe de Actividades Culturales. Como los juegos de Rafael Chaves, se inspiran en el humanismo cristiano: dan pie a la distensión, la iniciativa, los afectos. Pero permanece el panóptico vigilante y sigue exigiéndose uniformidad, movimientos automáticos, irreflexivos en los saludos, desfiles, genuflexiones.

Estas actividades recreativas, además, refuerzan la masculinidad o el sexismo, auténtico refugio y compensación (estrategia de distinción, diría Bourdieu) para los súbditos: algunas canciones resaltan las cualidades supuestamente superiores de los que realmente son domesticados: amor por la aventura («El bergantín»), dominio sobre la mujer-objeto, como refleja este «Poupurrit montañés»:

${ }^{67}$ Manual de campamentos (1948), 219-363. Devís, Atienza y Peiró, «Rafael Chaves...», 81-96. 
Dorotea, Dorotea

Dorotea, como eres tan fea

al verte la cara

me da no se [sic] qué.

$\mathrm{Y}$ al mirarte, $\mathrm{y}$ al mirarte

la cara que pones

se asustan las vacas, la burra

y los chones. 68

\section{CONCLUSIONES: REFERENTES Y RECEPCIÓN}

\section{Referentes. Afinidad entre cultura política y normalización de los cuerpos}

Los manuales de campamentos dibujan, representan el Estado y el régimen franquista, ideologías particulares (esencialmente subculturas falangista y católica) que lo sustentan y su evolución, siempre en correspondencia con una determinada política del cuerpo. Tienen como referente el Estado franquista, porque prefiguran su estructura orgánica y práctica gubernamental, incluidos los aspectos que atañen a la biopolítica: instalaciones sanitarias, aprovisionamiento y almacenamiento de alimentos, cálculo de calorías para conservar el pulso vital de los acampados.

Son referentes de esos manuales también el catolicismo (el Caballo de Troya en el seno del FJ) y el falangismo. Es obvio que FET-JONS marca una fuerte impronta en el sistema escolar (Educación Física, FEN), la educación de adultos, la cultura de masas, los campamentos... ${ }^{69}$ Pero su ideología solo puede subsistir, discretamente, como subcultura en mezcolanza con otros valores compartidos en mayor o menor medida por las demás elites de extracción del régimen. Así ocurre en los manuales de FEN o en los manuales de campamentos. Incluso el editado en 1943, en la Era Azul, comparte espacios con otras subculturas: católica, tradicionalista, militar. Su fracaso cultural se hace más evidente en el editado en 1948, que legitima la encíclica Divini Illius Magistri: no puede ser más

\footnotetext{
${ }_{68}$ Manual de campamentos (1948), 451-452. Resto información: 365-473, 432, 451.

${ }^{69}$ Florentino Sanz Fernández, «Las otras instituciones educativas de la postguerra española», Revista de Educación, extraordinario (2000): 333-358.
} 
dramática la decepción de los que hablan de revolución, Estado totalitario, estatalización de la enseñanza.

Esa debilidad deriva de factores contextuales (desde 1945 el ideal revolucionario resulta anacrónico), de la pérdida de peso político de FET-JONS (el que ganan los católicos con el cambio de gobierno de 1945) y de los escasos medios, afiliación y arraigo del partido y sus organizaciones, que cometen, además, el dislate de «predica[r] la revolución al abrigo de los Presupuestos Generales del Estado».${ }^{70}$ Fracasa la SF, por la contradicción entre los valores que predica (sumisión, fragilidad de la mujer) y la superación personal que exigen las competiciones femeninas. ${ }^{71}$ Fracasa el FJ en su intento de monopolizar el control de las juventudes; ${ }^{72}$ en las escuelas del Patronato Escolar, por no poder orientar el currículum; en los campamentos, por la falta de recursos; en la asignatura de FEN, sometida a los dictados del régimen y que, según algunas encuestas, apenas incidió en las actitudes sociales de los alumnos. ${ }^{73} \mathrm{El}$ FJ, según Franco «la obra predilecta del régimen», no fue un «Frente», sino una yuxtaposición de escolares y aprendices, ni «de Juventudes» (muchos lo abandonaron prematuramente por trabajo o estudios), y sus finanzas dependían de otras instancias (Ministerio de Educación, Delegación de Sindicatos.... ${ }^{74}$

A esas dos subculturas corresponden también dos maneras distintas de normalizar el cuerpo de los acampados. FET-JONS incide en la uniformización, en la geometría de las tablas gimnásticas, en la fortaleza, en la seguridad del gesto, en la masculinidad y la marcialidad: los cuerpos describen líneas rectas, expresión de la impronta castrense y del vitalismo y del optimismo revolucionario. La Iglesia impone la mansedumbre,

\footnotetext{
${ }^{70}$ Ricardo L. Chueca Rodríguez, «Las juventudes falangistas», Studia Historica. Historia Contemporánea 5 (1987): 87-104.

${ }^{71}$ Gonzalo Ramírez Macías, «La educación física y el deporte como medios de transgresión del modelo de mujer durante la dictadura franquista», Movimiento Vol. 24, n. ${ }^{\circ} 1$ (2018): 331-344. Ver también: M. ${ }^{a}$ Luisa Zagalaz Sánchez, «La educación física femenina durante el franquismo. La Sección Femenina», Apunts. Educación Física y Deportes 65 (2001): 6-16.

72 José Luis Rodríguez Jiménez, Historia de la Falange Española de las JONS (Madrid: Alianza, 2000), 490-492.

73 José Ignacio Cruz Orozco, El yunque azul. Frente de Juventudes y sistema educativo. Razones de un fracaso (Madrid: Alianza Editorial, 2001), 99, 132, 143, 223, 237.

${ }^{74}$ Sáez, El Frente de Juventudes, 481-487.
} 
el fervor, el recogimiento: los cuerpos describen líneas sinuosas, expresión del arrepentimiento, del pesimismo antropológico, de la indeleble marca del pecado original. Pero, igual que conviven la subcultura católica y falangista, en los manuales también conviven las formas de control corporal que les son propias. El panóptico del Jefe de Campamento, que todo lo ve y todo lo sabe, es compatible con el panóptico del Capellán, interesado especialmente en la vigilancia y control de la desnudez, de las pulsiones. Conviven las liturgias, dado que FET-JONS fue incapaz de crear una liturgia civil propia, independiente de la religión tradicional. En los actos religiosos conviven la verticalidad (posición de firmes en el acto de consagración) y la sinuosidad (comunión, confesión de rodillas). Y valores relacionados con el cuerpo: espíritu de sacrificio, renunciamiento y mortificación son -expresamente- compartidos por el catolicismo y el falangismo.

Los manuales también refieren la evolución del régimen. La edición de 1943 apuntala la creación de un estado totalitario. La edición de 1948 es el espejo diáfano de la desfascistización del régimen, de la construcción de un Estado católico. El «modo de ser falangista» es cada vez más el «"modo de ser” del caballero español», henchido de valores religiosos y patrióticos. La Formación Nacionalsindicalista se convierte en Formación Política. La revolución, en justicia social: como en la doctrina de la Iglesia. El ideal jerárquico, orgánico y corporativo que niega el liberalismo y la democracia, se expresa en términos eclesiales: colaboración, hermandad.

Como no podía ser de otro modo, esa evolución implica también cambios en la práctica gubernamental. La «ciudad de lona» de la edición de 1943 es un panóptico parecido al Estado totalitario que se estaba imponiendo en España. En la edición de 1948, mientras el panóptico del Jefe pierde peso en favor de la autodirección, igual que en la Organización Sindical se impone el corporativismo al verticalismo, el panóptico del Capellán se enriquece añadiendo a su inquisición moral funciones discursivas: la «Máxima religiosa» compite con las «Consignas» en que, de otra parte, se suaviza el ímpetu «revolucionario». Y cambios en la normalización de los cuerpos. Al hilo del autodenominado humanismo cristiano y de la revitalización de los principios pedagógicos del Padre Manjón y otros autores católicos (motivación positiva, iniciativa, cooperación activa, sistema mutuo), gana peso la distensión frente a la rigidez: se impone la línea quebrada y ondulada de los juegos predeportivos 
o las actividades voluntarias. Se pretende recuperar al HOMBRE (con mayúsculas), negando implícitamente el Estado totalitario. Pero el súbdito participante resultante debe reaccionar con movimientos automáticos en la celebración de la misa, las formaciones... Y, sobre todo, debe interiorizar determinadas normas (autodirección, autocastigo), que ya no están fuera, sino dentro de él mismo: habría que poner en entredicho, por tanto, ese supuesto humanismo.

Por encima de subculturas o de etapas, ambas ediciones coinciden en la legitimación de un referente que, aunque flexible, es idéntico a sí mismo, el franquismo. Ya hace tiempo Manuel Ramírez identificó los rasgos de una ideología franquista, aunque no fuera un todo articulado. ${ }^{75}$ Son aproximadamente los valores constantes que observamos en las ediciones de 1943 y 1948 del Manual de campamentos afines a eso que llamamos cultura del súbdito. Valores sociales: visión armoniosa de la sociedad, organicismo, promesa de redención, se llame «Revolución nacionalsindicalista» (1943) o «Justicia social» (1948). Valores políticos: nacionalismo, rechazo del individualismo y del liberalismo, encuadramiento orgánico, jerarquía, sumisión total a la autoridad civil y religiosa. Valores culturales: ideales de sacrificio, abnegación, servicio, paternalismo, sexismo y negación de la coeducación, vigilancia del placer sexual. Afectos: amor a Dios, a la Patria, al Jefe, alegría, vitalismo, camaradería... Quizás tenga razón Javier Tusell al afirmar que el catolicismo durante el franquismo pone veto al totalitarismo falangista, pero, el $\mathrm{Ca}$ tecismo Patriótico de Fray Albino Menéndez Reigada (1938), no oculta que el catolicismo aspiraba a un control total de la sociedad, al «totalitarismo cristiano».76 A esos valores constantes corresponde una normalización de los cuerpos constante. Desde el punto de vista de la práctica gubernamental, el campamento, tanto en 1943 como en 1948, funciona como un cuerpo, como un microcosmos orgánico, más próximo al verticalismo falangista en 1943, más próximo al corporativismo católico (hermandad, colaboración) en 1948. Al servicio de ese cuerpo están los cuerpos de los acampados, uniformados, obligados a movimientos automáticos o a describir líneas rectas (masculinidad, fuerza, arrojo, revolución,

\footnotetext{
${ }^{75}$ M. Ramírez, España, 1939-1975. Régimen político e ideología (Barcelona: Guadarrama-Punto Omega-Labor, 1978), 37, 67, 111.

76 Javier Tusell, Franco y los católicos. La política interior española entre 1945 y 1957 (Madrid: Alianza, 1984), 445-448; Menéndez-Reigada, Catecismo patriótico español (Barcelona: Península, 2003), 76.
} 
militarismo), sinuosas (mansedumbre, fervor) y quebradas u oblicuas (distensión dentro del sistema).

\section{Recepción: dificultades}

No es fácil extraer conclusiones sobre la recepción de estos manuales. Desde un punto de vista cuantitativo, lo dificulta la deficiente conservación de los archivos del FJ. ${ }^{77}$ Desconozco estudios sobre, por ejemplo, las tiradas de estos manuales, el número de receptores (mandos e instructores) que los pudieron manejar. Los datos disponibles son muy genéricos: hubo uno o dos campamentos por provincia (en 1960 figuran 65); el número de acampados entre 1937 y 1962 fue de 974.239 (894.683 en campamentos provinciales y 79.556 en campamentos nacionales). En 1943, año de la segunda edición del manual, 46.258 (44.916 en los provinciales y 1.342 en los nacionales); en 1948 -cuarta edición-, 46.476 acampados (42.529 en provinciales y 3.947 en nacionales). ${ }^{78}$

Más difícil resulta hacer una valoración cualitativa de la recepción, es decir la repercusión de los manuales de campamentos en la socialización de los españoles. Solo podemos aventurar que el FJ no pudo imponer su doctrina, pero contuvo a la juventud española más inquieta; ${ }^{79} \mathrm{y}$, paradójicamente, fomentó la utopía revolucionaria en una minoría, aunque en sentido contrario al pretendido, pues acabó dirigiéndose contra el régimen. ${ }^{80}$ Difícil también es saber cómo contribuyó el sistema de campamentos al sostenimiento del régimen, o a la conservación de valores que, según Paloma Aguilar, perviven más allá de 1975: supeditación de la libertad al orden; mayores reservas para expresar opiniones políticas; opinión negativa de partidos y sindicatos, con tasas de afiliación inferiores al resto de Europa; bajo nivel de preferencia por un sistema democrático en las opciones políticas de derecha... ${ }^{81}$ Los campamentos

\footnotetext{
77 José María Fernández Hevia, «Fuentes documentales para el estudio de la política de juventud durante el franquismo: las Delegaciones Provinciales del Frente de Juventudes», AABADOM 13 (2002): 29-40.

78 Sáez, El Frente de Juventudes, 418.

${ }^{79}$ Fernández Quevedo, Las actividades de «Aire libre», 465.

80 Sáez, El Frente de Juventudes, 487.

${ }^{81}$ Paloma Aguilar Fernández, Políticas de la memoria y memorias de la política (Madrid: Alianza, 2008), 381-411.
} 
quizás contribuyeron a reforzar esos valores en un sector de la población. Quizás reforzaron otros relacionados el cuerpo: diferencias más marcadas de los habitus (pose, formas de moverse, comportarse) y roles de hombres y mujeres que en los países del entorno, por la separación FJ/SF o la práctica desaparición de la coeducación; mayor contención sexual y sentimiento de culpabilidad respecto a prácticas como la masturbación o la homosexualidad, como consecuencia del peso de la Iglesia en la sociedad; la actitud reverencial ante lo sagrado tan cultivada en los campamentos. Parece que la rectitud y verticalidad propios de la subcultura falangista son habitus que, faltos de continuidad, no han conseguido naturalizarse. Sin embargo, las líneas sinuosas de la subcultura católica han venido reproduciéndose de forma más continua en actos religiosos o a través de la asignatura de religión católica, ya tamizada por el Concilio Vaticano II: miedo al cuerpo; concepciones muy tradicionales sobre la masturbación, la homosexualidad, la diferenciación de géneros; exaltación del dolor, de la castidad, la mansedumbre; actitud de recogimiento en las celebraciones litúrgicas. ${ }^{82}$

\section{Nota sobre el autor}

Emilio Castillejo Cambra es doctor en Historia por la Universidad Pública de navarra (UPNA): Actualmente jubilado, ha ejercido su labor docente como profesor de Historia en Institutos de Educación Secundaria, el Centro Asociado de la UNED en Pamplona y la UPNA. Entre sus publicaciones destacan los libros Mito, legitimación y violencia simbólica en los manuales escolares de Historia del franquismo, 1936-1975 (Madrid: UNED-Serie MANES, 2008) y La enseñanza de la religión católica en España desde la Transición (Madrid: La Catarata, 2012).

\section{REFERENCIAS}

Aguilar Fernández, Paloma. Políticas de la memoria y memorias de la política. Madrid: Alianza, 2008.

Almond, Gabriel A. y Sidney Verba. «La cultura política». In Diez textos básicos de Ciencia Política, edited by Albert Batlle, 171-190. Barcelona: Ariel, 1992.

82 Castillejo, La enseñanza de la Religión católica, 30-31, 97-105. 
Ascunce, José Ángel. Sociología cultural del franquismo, 1936-1975. Madrid: Biblioteca Nueva, 2015.

Bourdieu, Pierre. Cuestiones de sociología. Madrid: Istmo, 1999.

Bourdieu, Pierre. La dominación masculina. Barcelona, Anagrama, 1999.

Bourdieu, Pierre. Meditaciones pascalianas. Barcelona: Anagrama, 1999.

Burleigh, Michael. Poder terrenal. Religión y política en Europa. De la revolución francesa a la I Guerra Mundial. Madrid: Taurus, 2005.

Burleigh, Michael. Causas Sagradas. Religión y política en Europa. De la Primera Guerra Mundial al terrorismo islamista. Madrid: Taurus, 2006.

Campos, Ricardo. "Psiquiatría, raza y represión en el primer franquismo: Antonio Vallejo Nágera». In Los intelectuales y la dictadura franquista. Cultura y poder en España de 1939 a 1975, edited by Antonio Altarrabia et alteri, 19-45. Madrid: Editorial Pablo Iglesias, 2014.

Cañabate, José. A. «La pugna entre la Iglesia católica y el Frente de Juventudes en el ámbito educativo. Referencias internacionales, antecedentes y trayectoria general durante el primer franquismo». Historia de la Educación 22-23 (2003-2004): 105-121.

Capitán Díaz, Alfonso. «Humanismo pedagógico en la España Contemporánea, 1875-1951». Revista Española de Pedagogía 223 (2002): 461-480.

Carral Maseda, Diego. «Modesto Bargalló: el arte de educar en la naturaleza». Actas del XVIII Coloquio de Historia de la Educación Vol. 2 (2015): 481-486.

Castillejo Cambra, Emilio. Mito legitimación y violencia simbólica en los manuales escolares de Historia del franquismo, 1936-1975. Madrid: UNED-Serie MANES, 2008.

Castillejo Cambra, Emilio. La enseñanza de la Religión católica desde la Transición. Madrid: La Catarata, 2012.

Castillejo Cambra, Emilio. «Análisis del contenido ideológico de los manuales de Historia». Bordón Vol. 61, n. 2 (2009): 45-57.

Castillejo Cambra, Emilio. «Educación en el franquismo nacionalcatólico. La negación de la libertad y de la igualdad». In El artículo 27 de la Constitución: Cuaderno de quejas, coords. por Manuel de Puelles Benítez y Manuel Menor Currás, 53-75. Madrid: Morata, 2018.

Cayuela Sánchez, Salvador. Por la grandeza de la Patria. La biopolitica en la España de Franco, 1939-1975. Madrid: FCE, 2014.

Cayuela Sánchez, Salvador. «El nacimiento de la biopolítica franquista. La invención del "homo patiens"». Isegoría 40 (2009): 273-288.

Cayuela Sánchez, Salvador. «La biopolítica del franquismo desarrollista: hacia una nueva forma de gobernar, 1959-1975». Revista de Filosofía Vol. 38, n. ${ }^{\circ}$ (2013): 159-179.

Cenarro, Ángela. "Encuadramiento y consenso en la obra del Movimiento: mujeres, jóvenes y obreros». In Falange. Las culturas políticas del fascismo en la 
España de Franco (1936-1975), edited by Miguel Ángel Ruiz Carnicer, 199-216. Zaragoza: Institución Fernando el Católico-Diputación de Zaragoza, 2013.

Chueca Rodríguez, Ricardo L. «Las juventudes falangistas». Studia Historica. Historia Contemporánea 5 (1987): 87-104.

Cruz Orozco, José Ignacio. El yunque azul. Frente de Juventudes y sistema educativo. Razones de un fracaso. Madrid: Alianza Editorial, 2001.

Cruz Orozco, José Ignacio. «Nacionalcatolicismo en el Nacionalsindicalismo. Algunos ejemplos del Frente de Juventudes». Historia de la Educación 22-23 (2003-2004): 421-429.

Cruz Orozco, José Ignacio. «Falange, Frente de Juventudes y el nuevo orden europeo. Discrepancias y coincidencias en la política de juventud durante el primer franquismo». Revista de Educación 357 (2012): 515-535.

Cruz Orozco, José Ignacio. «Mientras España siga sin gustarnos, no podemos tener vacaciones. Una aproximación a los campamentos del Frente de Juventudes en la provincia de Valencia (1937-1955)». In Pedagogia. Pensament, política i pràctica. Lectures històriques en la societat valenciana contemporània, editado por Alejandro Mayordomo Pérez y Andrés Payà Rico, 59-77. Valencia: Tirant Humanidades, 2019.

Chueca Rodríguez, Ricardo L. «FET y de las JONS: la paradójica victoria de un fascismo fracasado». In España bajo el franquismo, edited by Josep Fontana, 60-77. Barcelona: Crítica, 2000.

Calle Valverde, Jaime De La. «El gesto analógico. Una revisión de las técnicas del cuerpo de Marcel Mauss». Revista Latinoamericana de Estudios sobre Cuerpos, Emociones y Sociedad 7 (2011-2012): 75-87.

Delegación Nacional del Frente de Juventudes. Manual de campamentos. Madrid: Ediciones Frente de Juventudes, 1943.

Delegación Nacional del Frente de Juventudes. Manual de campamentos. Madrid: Ediciones Frente de Juventudes, 1948.

Devis, José, Rodrigo Atienza y Carmen Peiró. «Rafael Chaves Fernández y el predeporte en la Educación Física del franquismo». Citius, Altius, Fortius Vol 3, n. ${ }^{\circ} 1$ (2010): 81-96.

Elias, Norbert. El proceso de la civilización. Investigaciones sociogenéticas y psicogenéticas. Madrid: F.C.E, 1993.

Ellwood, Sheelagh. Historia de Falange Española. Barcelona: Crítica, 2001.

Felipe Maso, José Luis. «La Institución Libre de Enseñanza: sus principios pedagógicos innovadores y su presencia en el currículo de la Educación Física actual. El primer centro docente español que utilizó el deporte como elemento educativo». Citius, Altius, Fortius, Vol. 7, n. ${ }^{\circ} 2$ (2014): 57-82.

Fernández Hevia, José María. «Fuentes documentales para el estudio de la política de juventud durante el franquismo: las Delegaciones Provinciales del Frente de Juventudes». AABADOM 13 (2002): 29-40. 
Fernández Quevedo Rubio, César. «Las actividades de «Aire libre» en la Organización Juvenil y el Frente de Juventudes». PhD diss., Universidad Complutense Madrid. Facultad de Educación. Departamento de Expresión Musical Corporal, 2018.

Foucault, Michel. Un diálogo sobre el poder. Madrid: Alianza, 1988.

Foucault, Michel. Historia de la sexualidad. I. La voluntad de saber. Madrid, Siglo XXI, 1992.

Foucault, Michel. Microfísica del poder. Madrid: La Piqueta, 1992.

Foucault, Michel. Vigilar y castigar. Nacimiento de la prisión. Madrid: Siglo XXI, 1992.

Foucault, Michel. Nacimiento de la biopolítica. Madrid: Akal, 2016.

Fullana, Pere y Feliciano Montero. «Los modelos educativos juveniles del movimiento católico en España (1868-1968)». Historia de la Educación 22-23 (2003-2004): 33-51

González Aja, Teresa. «Monje y soldado. La imagen masculina durante el franquismo». Revista Internacional de Ciencias del Deporte Vol. 1 (2005): 64-83.

Juliá, Santos. Historia de las dos Españas. Madrid: Taurus, 2004.

Kantorowicz, Ernst H. Los dos cuerpos del rey. Un estudio de teología política medieval. Madrid: Akal, 2012.

Koprinarov, Lazar. «La guerra en la paz: el uniforme militar y los preparativos antropológicos para la guerra». Thémata. Revista de Filosofía 48 (2013): 143151.

Maeztu, Ramiro de. Defensa de la Hispanidad. Madrid: Gráfica Universal Evaristo San Miguel, 1935.

Malvano, Laura. «El mito de la juventud a través de la imagen: el fascismo italiano». In Historia de los jóvenes. II. La Edad Contemporánea, dirigido por Giovanni Levi y Jean Claude Schmitt, 313-346. Madrid: Taurus, 1996.

Martínez Cuesta, Francisco Javier. «"Estaréis alegres en nuestra compañía”. Las actividades en los campamentos de la Sección Femenina (1942-1953)». El Futuro del Pasado 9 (2018): 61-84.

Martínez Gorroño, María. E. y Juan L. Hernández Álvarez. «La Institución Libre de Enseñanza y Pierre de Coubertin: la educación física para una educación en libertad». Revista Internacional de Medicina y Ciencias de la Actividad Física y del Deporte Vol. 14, n. ${ }^{\circ} 54$ (2014): 243-263.

Mauri Medrano, Marta. "Mens sana in corpore sano. La Educación Física del Frente de Juventudes y el disciplinamiento de los cuerpos». Actas del XVIII Coloquio de Historia de la Educación: Arte, literatura y educación, Vol. 1 (2015): 381-391.

Mauri Medrano, Marta. "Disciplinar el cuerpo para militarizar a la juventud. La actividad deportiva del Frente de Juventudes en el franquismo (1940-1960)». Historia Crítica 61 (julio-septiembre 2016): 85-103. 
Mauri Medrano, Marta. «El cuerpo juvenil sano como símbolo político del fascismo. La normalización de los cuerpos a través del discurso médico del fascismo». Riphe. Revista Iberoamericana. Patrimonio Histórico-Educativo Vol. 2, n. 3 (2016): 117-128.

Mauss, Marcel. Sociología y antropología. Madrid: Tecnos, 1979.

Menéndez-Reigada, Albino G. Catecismo patriótico español. Barcelona: Península, 2003.

Michaud, Eric. "Soldados de una idea”: los jóvenes bajo el Tercer Reich». In Historia de los jóvenes. II. La Edad Contemporánea, dirs. Giovanni Levi, Jean Claude Schmitt. 349-379. Madrid: Taurus, 1996.

Ortega y Gasset, José. La rebelión de las masas. Madrid: Austral, 2016.

Payne, Stanley G. Franco y José Antonio. El extraño caso del fascismo español. Barcelona: Planeta, 1997.

Pérez Ramírez, Carmen. «Evolución histórica de la Educación Física». Apunts: Educación Física y Deportes 33 (1993): 24-38.

Rabazas Romero, Teresa. "La educación física del Magisterio femenino en el franquismo». Revista Complutense de Educación Vol. 11, n. ${ }^{\circ} 2$ (2000): 167198.

Ramírez, Manuel. España, 1939-1975. Régimen político e ideología. Barcelona: Guadarrama-Punto Omega-Labor, 1978.

Ramírez Macías, Gonzalo. «La educación física y el deporte como medios de transgresión del modelo de mujer durante la dictadura franquista». Movimiento Vol. 24, n. ${ }^{\circ} 1$ (2018): 331-344.

Ramírez Rico, Elena, César Fernández Quevedo y Emilia Fernández García. «Las publicaciones sobre la organización del Frente de Juventudes (19401961). Adiestramiento de las mujeres en las actividades en la naturaleza». Historia y comunicación social 23 (2018): 257-272.

Reig Tapia, Alberto. "Aproximación a la teoría del caudillaje». Revista de Estudios Políticos (Nueva Época) 69 (1990): 61-81.

Robles, Elena, García Benavides, Fernando y Bernabeu Mestre, Josep. «La transición sanitaria en España desde 1900 a 1990». Revista Española de Salud Pública 70, n. ${ }^{\circ} 2$ (1996): 221-233.

Rodríguez Jiménez, José Luis. Historia de la Falange Española de las JONS. Madrid: Alianza, 2000.

Sáez Marín, Juan. El Frente de Juventudes. Política de juventud en la España de la posguerra, 1937-1960. Madrid: Siglo XXI, 1988.

Sanz Fernández, Florentino. «Las otras instituciones educativas de la postguerra española». Revista de Educación, extraordinario (2000): 333-358.

Serapilglia, Daniele. "L'uomo nuovo. Sport e corporativismo tra fascismo e cattolicesimo italiano nell'estado novo portoghese tra le due guerre». Hispania Nova 17 (2019): 235-269. 
Simón, J. Antonio. «Deporte y totalitarismo». Hispania Nova 17 (2019): 224234.

Simón, J. Antonio. «El deporte en el NO-DO durante el primer franquismo, 1943-1951». Hispania Nova 17 (2019): 341-371.

Somoza, Miguel, Kira Mahamud y Heloisa Helena Pimienta. «Emociones y sentimientos en los procesos de socialización política: una mirada desde la Historia de la Educación». Historia y memoria de la Educación 2 (2015): 7-44.

Thomàs, Joan Maria. Lo que fue la Falange. Barcelona: Plaza y Janés, 1999.

Torrebadella, Xavier. "La Educación Física Comparada en España (18061936)». Historia Social y de la Educación Vol. 3, n. ${ }^{\circ} 1$ (2014): 25-53.

Tusell, Javier. Franco y los católicos. La política interior española entre 1945 y 1957. Madrid: Alianza, 1984.

Tusell, Javier. Historia de España en el siglo XX. III. La Dictadura de Franco. Madrid: Taurus, 1998.

Villacañas, José Luis. Ramiro de Maeztu y el ideal de la burguesía en España. Madrid: Espasa, 2000.

Viñao, Antonio. Escuela para todos. Educación y modernidad en la España del siglo XX. Madrid: Marcial Pons, 2004.

Viuda Serrano, Alejandro. «Héroes de papel: el deporte y la prensa como herramientas de propaganda política del fascismo y el franquismo. Una perspectiva histórica comparada». Historia y Comunicación Social Vol. 17 (2012): 41-68.

Zafra, Remedios. El entusiasmo. Barcelona: Anagrama, 2017.

Zagalaz Sánchez, M. ${ }^{a}$ Luisa. "La educación física femenina durante el franquismo. La Sección Femenina». Apunts. Educación Física y Deportes 65 (2001): 6-16. 